\title{
Growth and absorption response of Eucheuma denticulatum (Burman) Collins \& Hervey) to fish farm water quality condition
}

\begin{abstract}
Two sampling sites (573m apart) were selected, one serves as the experimental site with floating cages for milkfish and pompano located near the coast, and the other representing the control site also with floating cages containing the same fish species located in a deeper area of the bay. Biomass and growth rates of E. denticulatum was measured on a monthly interval, along with physico-chemical parameters in the two sites, monitored for a period of up to one year. Results showed that seaweed species grew well within the conditions of the experimental fish farming site, where water temperature, salinity, $\mathrm{pH}$, dissolved oxygen were found to be well within the optimal range. Growth, aside from the seasonal changes in the weather pattern that influenced water movement, was affected by the presence of epiphytes, predators and fouling organisms that were present during culture. These factors have reduced potential biomass, nutrient absorption, and growth rates of the seaweeds. The introduction of the extractive species in the fish farm appeared to have checked the adverse effects of fish culture activities whose daily inputs of commercial feeds, aside from feces and metabolic wastes, could be the main contributor to the suspended solids in the surrounding waters. The levels of ammonia at $0.5 \mathrm{~m}$ (average: $0.047 \mathrm{mg} / \mathrm{L}$ ) in the experimental site was observed to be lower than that of the control site, whereas the levels of nitrate (ave: $0.226 \mathrm{mg} / \mathrm{L}$ ) and phosphate (ave: $0.149 \mathrm{mg} / \mathrm{L}$ ) in the same depth remained relatively high suggesting that these nutrients were not absorbed much.
\end{abstract}

Keywords: commercial fish culture, IMTA, eucheuma denticulatum, chanoschanos, trachinotus blochii
Volume 10 Issue 4 - 202I

\author{
Adriano R Melendres \\ Fisheries Department, Cebu Technological University, Philippines
}

Correspondence: Adriano R Melendres, Fisheries

Department, Cebu Technological University - Carmen, Cebu,

Philippines, Email adrianojr.melendres@ctu.edu.ph

Received: August 20, 202I | Published: September 13,2021

\section{Introduction}

Monoculture is common in marine aquaculture which a few studies credit to ecological harm because of its constant development. ${ }^{1-3}$ The culture of high value species (e.g. milkfish and pompano) in coastal waters relies on commercial feeds and has a negative impact on water quality. On the sea dynamics and environmental side, just a minor piece of the nutrients from the feeds are fixed by the fish, $14-30 \%$ of the nitrogen, $20-42 \%$ of the phosphorus, ${ }^{4}$ and the larger part become solid wastes which, in this way, could contaminate the sea area. Integrated culture of helpful and functional species to utilize the excess nutrients is presently looked into as a potential solution. Growing of a few animal types in a biologically designed aquaculture, polyculture, and integrated aquaculture frameworks is the idea of IMTA - Integrated Multi-trophic Aquaculture being coined in 2004 by Chopin and Robinson. IMTA approach speaks to a type of manageable aquaculture as it includes raising an assortment of animal varieties from various trophic levels in a single site. This is to alleviate such an issue in nutrient loads from finfish monoculture. ${ }^{5}$ Integrated mariculture systems are classified into three types as distinguished from each other according to specific species and design. ${ }^{6}$ These are; 1) tank cultures (for fish based systems), 2) pond cultures (e.g., fish and shrimp-based systems) and (3) open-water cultures (for fishbased systems).

Eucheumatoid cultivation methods by farm workers were usually set by raft bamboo and developed to a long line method in Indonesia. ${ }^{7}$ The cultivation of seaweeds in fish cages promotes higher productivity levels and with less variability than natural seaweed beds due to higher and more constant nutrient availability. ${ }^{8}$ Inorganic forms of nutrients will not be digested totally by the fed fish and portions will end up in the feces. ${ }^{9}$ In 2016 alone, world fresh weight seaweed production had reached to $30,139,389$ t. ${ }^{10}$ The main producer countries in South-east Asian regions were; China, Indonesia, Philippines and the Korea. ${ }^{10}$ The Philippines to the present still plays a vital role in seaweed exportation. The culture of red seaweeds is practical because of their huge demand in the world market aside from their beneficial effect on the surrounding ecosystems. In open-culture systems, such as fish cage farming, only a few studies have investigated the possibilities of integrating seaweed farming. The importance in IMTA is not about the dilution of the nutrients in the water of how far these nutrients are dispersed in the water but rather on the conversion of these nutrients to create products in terms of assimilative and extractive species growth - bioremediation functions of this species. Seaweeds like Kappaphycus alvarezii can remove the excess nutrients from an intensive fish farm. ${ }^{11}$ Thus, this study was aimed at determining the utilization of the available nutrients in the milkfish-pompano farm for 40 days having 4 planting cycles in Valladolid, Carcar, Cebu, Philippines. The specific objectives are; to determine the growth, quantify the assimilative role of the species to inorganic nutrients, and monitor in situ the changes in physico-chemical parameters during seaweed culture period.

\section{Materials and methods}

\section{Description of study site}

IMTA cultures were investigated in the fish cage culture operation near the Bolinawan islet in Carcar Bay - the southern part of Cebu, Philippines (Figure 1a). The fish farms and its 30 hectares fish ponds 
were established in the early years of 2000 and fully operational in 2003. The experimental fish cages site was within 10.081.27' $\mathrm{N}$ and 123.649.67' E, surrounding plots from $10.078 .90^{\prime} \mathrm{N}$ and $123.666 .16^{\prime} \mathrm{E}$, to adjacent $10.081 .04^{\prime} \mathrm{N}$ and $123.649 .57^{\prime} \mathrm{E}$ in Valladolid, Carcar, Cebu where the seaweed farming culture were deployed to a $45 \mathrm{~m}$ (30 $\mathrm{m}$ inside and $15 \mathrm{~m}$ outside plot) horizontal distance (Figure $1 \mathrm{~b}$ ). The privately-owned coastal and open water fish farm has been used for silver pompano (Trachinotus blochii) and milkfish (Chanos chanos) production (including breeding production), while tilapia and the brackish water prawn (Penaeus vannamei) has been cultured in the land-based fish ponds. For this study, two sets of fish cages were utilized - experimental (square fish cages) and control set (INCA, circular fish cages). Fish farming operations in this area started in 1987.

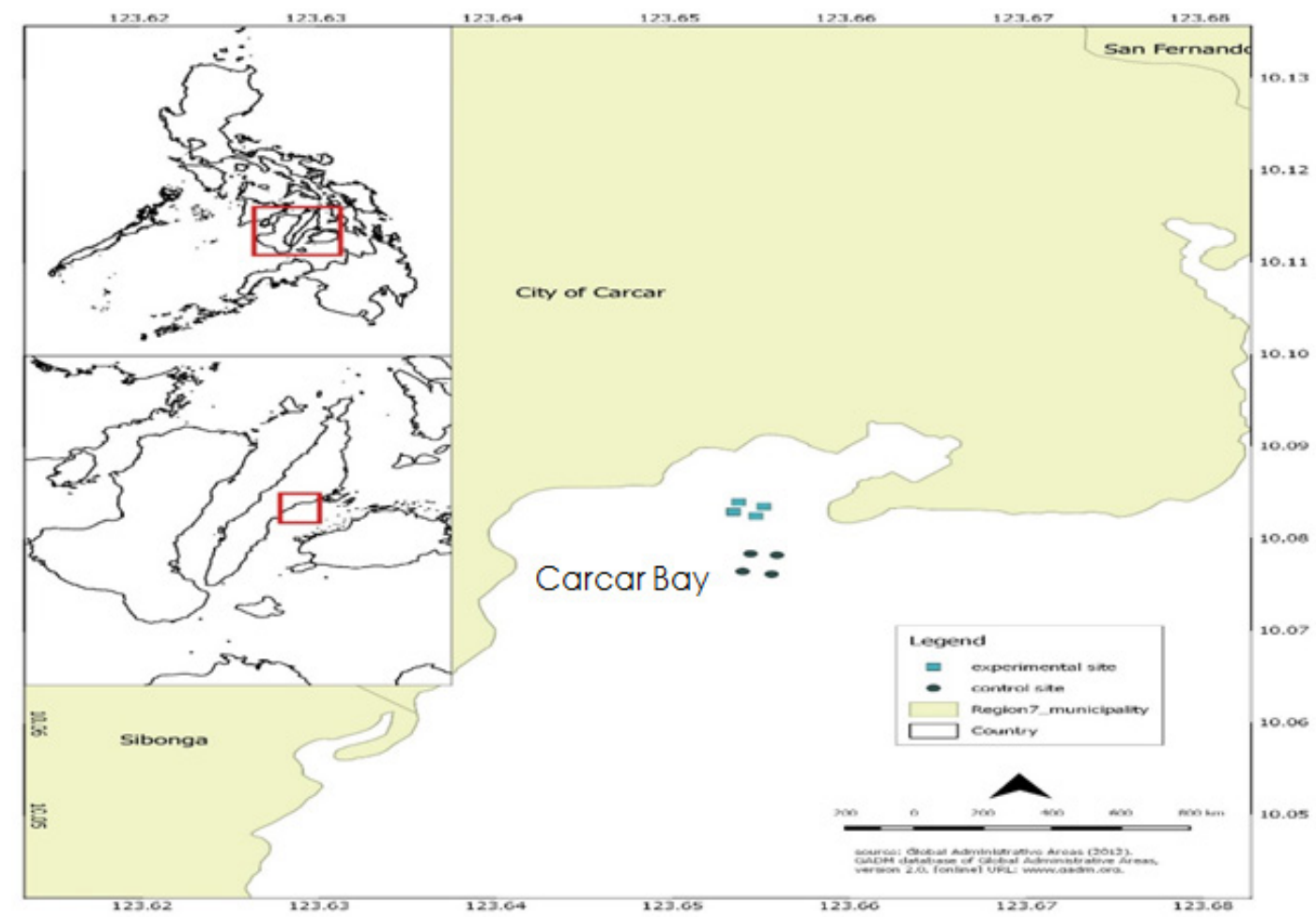

Figure Ia Geographical location of the fish farm showing the experimental and control sites within Carcar Bay, Cebu, Philippines.

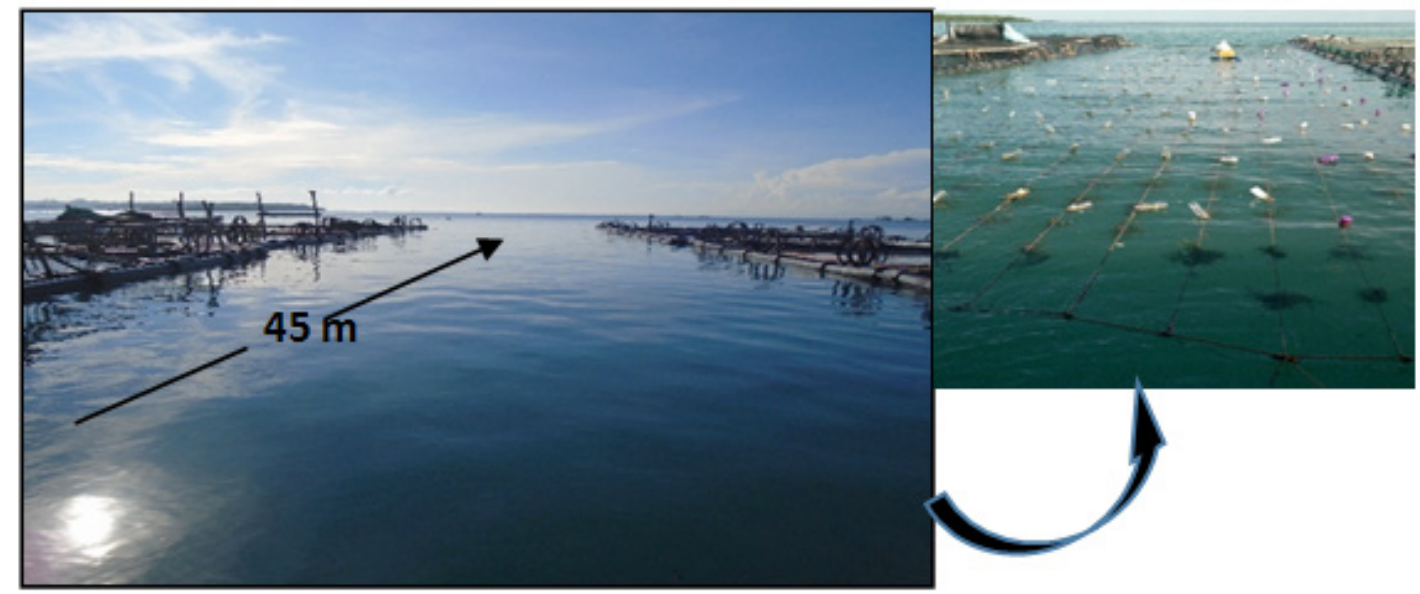

Figure Ib Culture area of Eucheuma denticulatum placed between fish cages.

The experimental set was composed of ten (10) square cages arranged into two rows of five cages each. Each cage can accommodate a stocking density of up to 25 thousand milkfish fingerlings and juveniles, and 20 thousand silver pompanos deployed at depths of up to $15 \mathrm{~m}$ during low tides. On the other hand, the control set was composed of 10 circular INCA floating cages (Specifications: 10 UV-stabilized double collar stanchions, High-Density Polyethylene
(HDPE) flotation with polystyrene inserts, roto-molded PE stands, and UV-stabilized black PE handrail covered with PE nets. These cages were deployed at depths of up to $35 \mathrm{~m}$ during low tides. Exclusively for juvenile and mature milkfishes having a density of more than 80,000 fishes per cage in less than 3 months culture. The distance between the experimental and control site was 573 meters. 


\section{Source of seaweed planting materials, setting up of culture ropes, and planting scheme}

The culture of Eucheuma species has been practiced within the Carcar Bay, less than $2 \mathrm{~km}$ from Bolinawan islet. Over 100kg of $E$. denticulatum, purchased from a seaweed grower in the Carcar Bay area, was replanted in the experimental site. Prior to planting, the cultivars were cleaned of epiphytes and thallus parts with ice-ice disease were removed. Seedlings/cultivars had an initial average weight of 155 to 160 which were tied individually with plastic straws ('tie-tie') into culture ropes (PE rope, \#18) having 30m lengths, arranged in parallel $(50-70 \mathrm{~cm}$ apart) at the vacant space $(10 \mathrm{mx} 30 \mathrm{~m}$, or $300 \mathrm{~m}^{2}$ ) between fish cages (see Figure 1b). 100 pcs of tagged seedlings were tied with yellow plastic straw at random from 9 culture ropes (as inside plot). Seedlings were retied at an interval of $10-15 \mathrm{~cm}$ in the culture ropes and remained there for 40 days. Another $350 \mathrm{~kg}$ of seaweeds were reserved to replace any seedlings lost during each culture period. Every after harvest, at the end of 40 days, a new batch of seedlings were replaced into the culture ropes. Additional culture ropes were set up outside the fish culture area as an extension plot. This extension plot was close to one-half (about $150 \mathrm{~m}^{2}$ ) of the entire seaweed culture area with 7 culture lines (see Figure 1b). All culture ropes were fixed near the surface $(0.5 \mathrm{~m}$ depth) with styrofoam balls and empty plastic bottles.

A total of 1,560 seedlings were hanged in the culture ropes during the 4 planting or culture cycles: $650 \mathrm{pcs}$ in $1^{\text {st }}, 400$ in $2^{\text {nd }}, 210$ in $3^{\text {rd }}$, and $300 \mathrm{pcs}$ in $4^{\text {th }}$ cycle. Cleaning of the ropes and cultivars from epiphytes, and other macroalgal growth and parasites were performed twice a month. This procedure followed the conventional way of farming the eucheumatoids using the floating raft technique as discussed by Pereira and Yarish in 2008. Four rounds of seaweed culture were performed between November 2018 and May 2019: 1) November 7 to December 17, 2018, 2) January 29 to March 15, 2019, 3) March 14 to April 23, and 4) $3^{\text {rd }}$, and April 1 to May 10, 2019. Growth validations and observations were made relative to its assimilative role for micronutrients within the fish cage ambient seawater.

\section{Growth rate monitoring}

The growth performance of Eucheuma denticulatum were monitored for 4 planting cycle and per cycle were measured four times using commercial plastic weighing scale (max. $2 \mathrm{~kg}$ ): 1) during planting, 2) after 15 days, 3) after 30days, and 4) after 40 days of exposure within the fish cage environment. 40 to 45 pcs of tagged seedlings were picked at random for every sampling dates from the culture ropes. After 40 days, the matured cultivars were then harvested, while the majority of the cultivars were splitted into several pieces and restored back to their original average weight of 155 to $160 \mathrm{~g}$ each, and retied directly to the culture ropes for another planting cycle phase (40 days). Increased in growth was determined in terms of wet weight using a spring balance (max. $2 \mathrm{~kg}$ ) between 9 and 10AM. After weighing, the seedlings were immediately returned to the culture ropes to avoid unnecessary exposure to air and desiccation. Lost seedlings from the culture lines were replaced with new cultivars from the reserved stock.

Daily Growth Rate (DGR) of seaweeds in the experimental fish cage station is calculated using the formula:

$\mathrm{DGR}=\ln \left(\mathrm{W}_{\mathrm{f}}-\mathrm{W}_{\mathrm{i}}\right) \mathrm{X} 100 / \# \mathrm{~d}^{12}$

Where: In $=$ normal $\log$ of the quotient of final weight $\left(\mathrm{W}_{\mathrm{f}}\right)$ over initial weight
$\left(\mathrm{W}_{\mathrm{i}}\right)$

$\# \mathrm{~d}=$ number of culture days.

\section{Water quality monitoring}

Water samples for nutrient analysis (ammonia, nitrate, phosphate, TDS and TSS) were taken every month for four months (August to November 2018), i.e., before the deployment of IMTA species, to serve as baseline data for the study site. A $1.5 \mathrm{~L}$ samples were taken using an improvised $1.5 \mathrm{~L}$ water sampler during sampling schedules at 1:00 to $2: 00 \mathrm{PM}$ in three random areas from within the sub-surface ( $0.5 \mathrm{~m}$ deep), placed into polyethylene bottles, and transported in icechilled condition to the Water Quality First Analytical Services and Technical Cooperative (F.A.S.T.) Laboratories in Mandaue City, Cebu within less than $24 \mathrm{H}$ from field collection.

During the seaweed planting period, from December 2018 to May 2019 , monthly water sampling continued in both experimental and control sites with four to five replicates starting from 9:00AM to 1:00PM. Samples were submitted to the USC Water Laboratory in University of San Carlos - Talamban Campus, for nutrient analysis using colorimetric and gravimetric methods. The data obtained during this phase were used to compare with the baseline data collected prior to IMTA deployment. Aside from nutrients, other physico-chemical parameters were taken in situ at twice a month, namely: water temperature and dissolved oxygen using an YSI 550A DO meter, salinity, using a digital refractometer (Trans Instruments), and $\mathrm{pH}$ using a digital $\mathrm{pH}$ meter (American Marine Inc. brand), respectively.

\section{Statistical analysis}

F comparison between two sites with an independent two-tailed test application to check the difference between nutrients in the experimental and control sites. Before the analysis data were tested for homogeneity of variance, growth rates were analyzed using oneway ANOVA to test the significant difference among the means of the growth rate of theseaweed sepcies. Tukey post hoc was applied for comparison respectively. The analysis was further verified using PAST vers. 3 software and Excel Data Analysis. All obtained data are shown herein at mean and standard deviation (SD) at significant p $<0.05$ levels. For minimum and maximum values, Excel 2013 was used to analyze for physicochemical parameters such as DO, temperature, salinity, and $\mathrm{pH}$.

\section{Results and discussion}

\section{Growth performance of Eucheuma denticulatum under IMTA set up}

The total biomass of Eucheuma denticulatum harvested after 40 days during November - December 2018 ( $1^{\text {st }}$ planting cycle $)$ was lowest among the 4 planting cycles in 2019 (Figure 2). Cumulative biomass production of $E$. denticulatum has reached a maximum average of $450 \mathrm{~g}$ after $40^{\text {th }}$ day from an initial average weight of $155 \mathrm{~g}$ that varies among the four planting cycles, e.g., a maximum of $553.25 \pm 108.32 \mathrm{~g}$ in the $1^{\text {st }}$ cycle, $650.79 \pm 113.30$ in the $2^{\text {nd }}$ cycle, $688.31 \pm 79.93 \mathrm{~g}$ in the $3^{\text {rd }}$ cycle, and $749.93 \pm 70.63 \mathrm{~g}$ in the $4^{\text {th }}$ cycle (Figure 3). The daily growth rates (DGRs) of E. denticulatum ranged from $1.22 \pm 0.73 \%$ day $^{-1}$ in the $1^{\text {st }}$ cycle to $3.12 \pm 0.12 \%$ day $^{-1}$ in the $2^{\text {nd }}$ cycle, although comparison of growth rates among the four culture cycles showed significant difference $(\mathrm{p}<0.05)$. High growth rates from April to May ( $4^{\text {th }}$ planting cycle - see Figure 3 ) could be attributed to better water exchange generated by strong water current and waves at certain times during northeast monsoon season. 

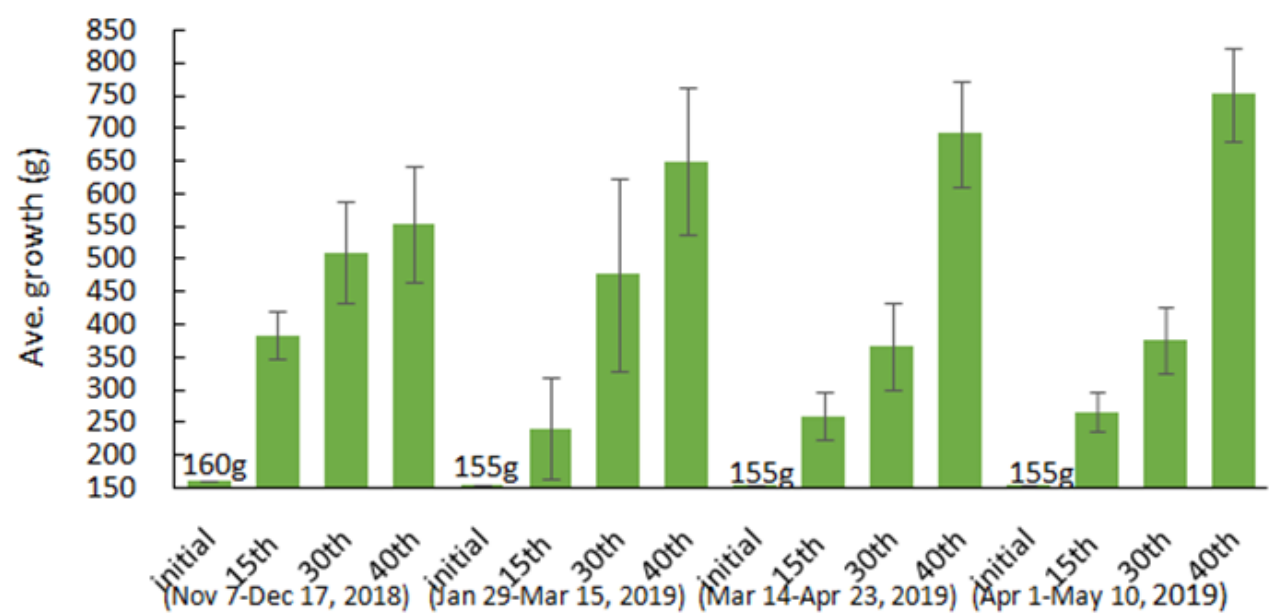

Figure 2 A 40-day biomass production $(n=40 \pm S D ; n=45 \pm S D)$ of $E$. denticulatum within experimental fish cages (depth, $0.5 \mathrm{~m}$ ) for November 2018 to May 2019 .

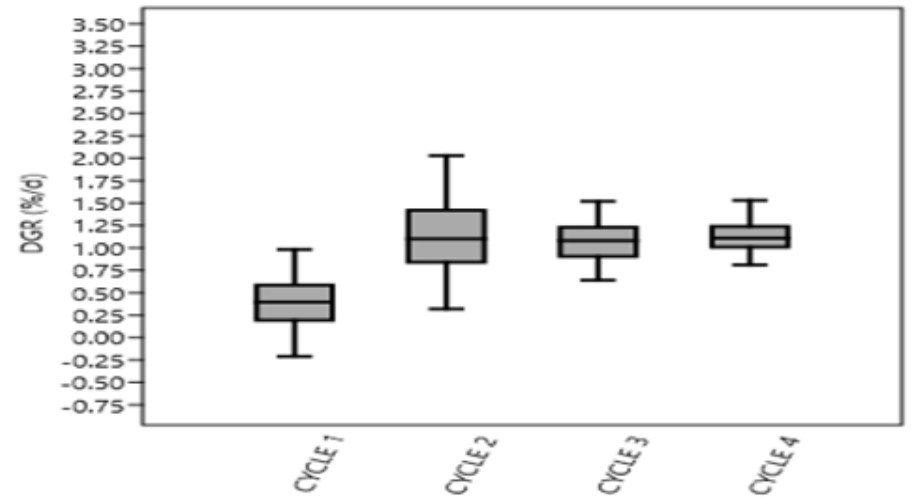

Figure 3 Growth rate of Eucheuma denticulatum $(n=40 ; 45 \pm S D)$ for 6 .

The same water conditions also caused not only the disarrangement of the bamboo frames, but also the breakage of some cultivars from the culture rope. On the other hand, during calm season (during April 2019), where water turbulence was less, epiphytes began to colonize the seaweed, covering much of the cultivars that have contributed to the rapid decrease in their growth rates during this period. Epiphytes could inhibit sunlight penetration into the cultivated seaweeds - a primary factor affecting seaweed cultivation (Vairappan, 2006). Aside from epiphytes, slow water movement allowed the microorganisms, such as, bacteria, fungi, and viruses to colonize the cultivars and damage the macro-algae during culture ${ }^{14}$ through their interactions with the cultivars during stressful times, resulting to ice-ice disease.

The average growth rate of E. denticulatum in the $1^{\text {st }}$ culture cycle and $4^{\text {th }}$ culture cycle was lowest during the first 15 days when herbivorous fish (e.g., rabbit fishes) were abundant around the cultivation area. However, average daily growth rates in the $2^{\text {nd }}, 3^{\text {rd }}$ and $4^{\text {th }}$ cycle still obtained $1.91 \pm 1.09,1.74 \pm 0.69$, and $1.85 \pm 0.54 \%$ day $^{-1}$ respectively. The drops in biomass were also due to prevailing factors aside from ice-ice, such as the occurrence of macro-epiphytes (Figure 4), and loss of cultivars due to strong waves brought about by typhoons in the months of March and May 2019, and northeast monsoon during the months of November to December. It was also during this March to May 2019 period where sporadic rains from typhoons occurred. The main drawback to the open water cultivation of seaweeds was the infrastructure required to support the seaweed cultivars in place during strong waves. More studies are required to improve the technology to be used for the IMTA system to work well.

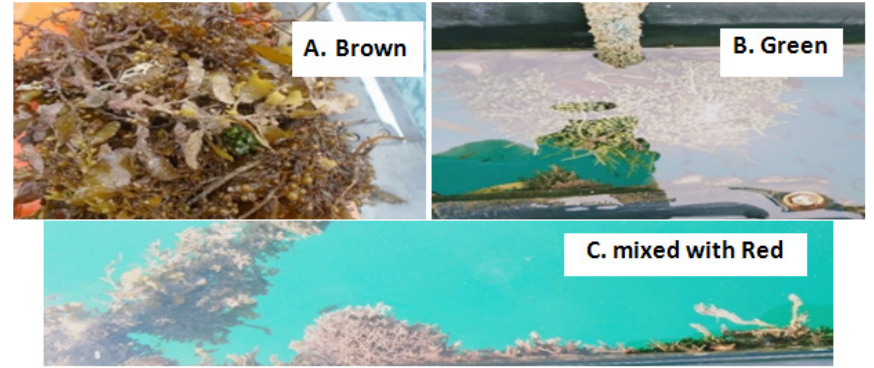

Figure 4 Occurrence of some macroalgae (dominated mainly by A. Brown) beside the experimental fish cage frame during the IMTA culture period January to July 2019.

Biomass production of $E$. denticulatum for $3^{\text {rd }}$ and $4^{\text {th }}$ cycle, besides the vacant space $(10 \mathrm{mx} 30 \mathrm{~m})$ and extension plot $(10 \mathrm{mx} 15 \mathrm{~m})$ perimeter of the floating cages was not comparable (Table 1). Cultivars $(\mathrm{n}=35-38)$ set between the fish cages had relatively low DGR (1.60 and $1.79 \%$, respectively) compared to those set beyond the floating fish cages $(n=7-10)$, with DGRs of 2.23 and $2.19 \%$, respectively. The water current outside the fish cage structures was unobstructed and must have freely shaken the seaweed cultivars resulting in their better growth than those cultured between the fish cages. The current speed measured outside the fish cages perimeter in January and April 2019, showed average values of 0.150 and $0.183 \mathrm{~m} \cdot \mathrm{sec}^{-1}$, respectively (data not shown). Favorable conditions instantaneous to constant water current, aside from optimum salinity in the area could have resulted 
in the better growth of E. denticulatum in the experimental site. ${ }^{15}$ The local growers in the Carcar Bay area also affirmed that water movement (mainly water current) provides better growth of seaweeds. So far, few studies comparing the growth of E. denticulatum under different cultivation methods using the IMTA approach have been made in the tropical region. Largo et al. ${ }^{16}$ reported the use of $E$. denticulatum as inorganic extractive IMTA species in the culture of donkey's ear abalone as fed species. More efforts are needed towards finding suitable extractive species to be cultured beside the fish cages especially for milkfish whose culture in the open sea is increasingly becoming popular in the Philippines.

Table I Comparison of the average daily growth rate (DGR) for $3^{\text {rd }}$ and $4^{\text {th }}$ planting cycle of the cultured Eucheuma denticulatum from outside and inside of the fish cage perimeter

\begin{tabular}{|c|c|c|c|c|c|c|c|}
\hline \multicolumn{2}{|c|}{ Parameters } & \multicolumn{3}{|c|}{ 3rd Planting cycle } & \multicolumn{3}{|c|}{ 4th Planting cycle } \\
\hline & Days & 15 & 30 & 40 & 15 & 30 & 40 \\
\hline \multirow{3}{*}{ Outside } & DGR $\left(\%\right.$ day $\left.^{-1}\right)$ & 1.87 & $\mathrm{I} .4 \mathrm{I}$ & 3.42 & 1.86 & 1.2 & 3.52 \\
\hline & SD & 0.20 & 0.42 & 0.71 & 0.1 & 0.49 & 0.88 \\
\hline & Ave & \multicolumn{3}{|c|}{2.23} & \multicolumn{3}{|c|}{2.19} \\
\hline \multirow{3}{*}{ Inside } & DGR $\left(\%\right.$ day $\left.^{-1}\right)$ & 1.34 & 0.87 & 2.59 & 1.47 & 0.96 & 2.95 \\
\hline & SD & 0.39 & 0.75 & 0.92 & 0.35 & 0.50 & 0.71 \\
\hline & Ave & \multicolumn{3}{|c|}{1.60} & \multicolumn{3}{|c|}{1.79} \\
\hline
\end{tabular}

45 cultivars ( 10 outside, 35 inside) for 3 rd cycle; ( 7 outside, 38 inside) for 4 th cycle

\section{Effects of the physico-chemical parameters to the cultured organisms}

Monthly average water temperature near the surface $(0.5 \mathrm{~m}$ depth) randomly measured in the morning and afternoon (with 4 to 5 replicates) in the two sampling stations for 12 months ranged from 27.20 to $30.79^{\circ} \mathrm{C}$ in the experimental zone and from 26.81 to $30.40^{\circ} \mathrm{C}$ in the control site (Table 2, Figure 5). Both sites are within the optimal requirements for the eucheumoids in the tropical region. Salinity values in both experimental (34 and 35psu) and control site ( 34.50 and $35.45 \mathrm{psu}$ ) were well within the normal range for marine waters and for the optimal growth requirements for Eucheuma, according to Lideman et al. ${ }^{17}$ A slight salinity drop in both sites in December 2018 and January 2019 could be due to the successive heavy rains before the measurements were being conducted.

Table 2 Physico-chemical parameters (random replicates, $\mathrm{n}=8$ to $10 \pm \mathrm{SD}$ per month) before and during planting periods in the experiment and control sites

\begin{tabular}{llllll}
\hline Treatment & & DO $(\mathbf{m g} / \mathbf{L})$ & $\mathbf{p H}$ & Salinity (psu) & Temp $\left({ }^{\circ} \mathbf{C}\right)$ \\
\hline \multirow{2}{*}{ Experimental } & Mos & 12 & 12 & 12 & 12 \\
& Min & $5.17 \pm 0.24$ & $7.64 \pm 0.15$ & $34.00 \pm 0$ & $29.27 \pm 0.14$ \\
& Max & $6.46 \pm 0.35$ & $8.22 \pm 0.10$ & $35.00 \pm 0$ & $30.79 \pm 0.27$ \\
& Mos & 12 & 12 & 12 & 12 \\
Control & Ave & $5.81 \pm 0.21$ & $8.01 \pm 0.15$ & $35.06 \pm 0.22$ & $29.12 \pm 0.25$ \\
& Min & $5.05 \pm 0.06$ & $7.72 \pm 0.07$ & $34.50 \pm 0$ & $26.81 \pm 0.02$ \\
& Max & $6.77 \pm 0.53$ & $8.34 \pm 0.13$ & $35.45 \pm 0.58$ & $30.40 \pm 0.65$ \\
\hline
\end{tabular}

Samples taken at $0.5 \mathrm{~m}$ depth

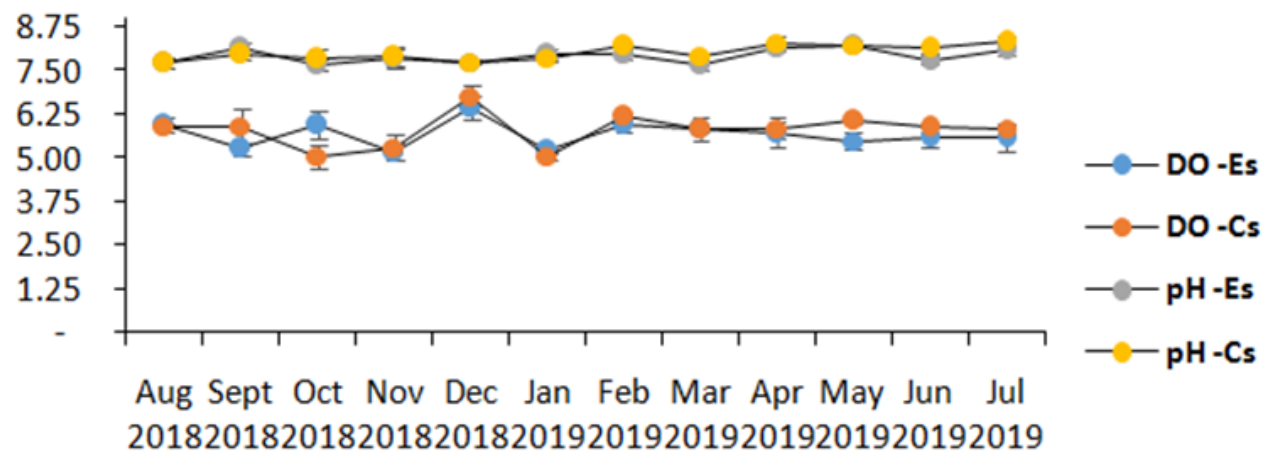

Citation: Melendres AR. Growth and absorption response of Eucheuma denticulatum (Burman) Collins \& Hervey) to fish farm water quality condition. J Aquac Mar Biol. 2021;I0(4): I78-I86. DOI: 10.15406/jamb.202I.10.00319 


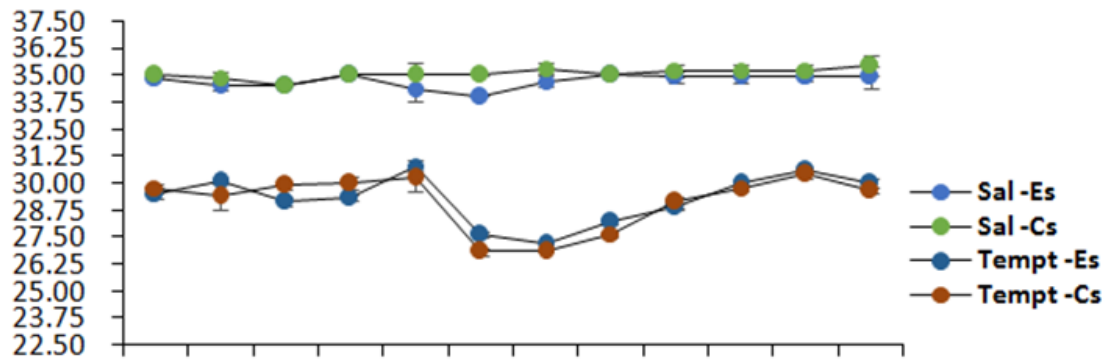

Aug Sept Oct Nov Dec Jan Feb Mar Apr May Jun Jul 201820182018201820182019201920192019201920192019

Figure 5 Monthly average $(\mathrm{n}=8 ; 10 \pm \mathrm{SD})$ measurement of the physico-chemical parameters $\left(\mathrm{DO}(\mathrm{mg} / \mathrm{L})\right.$, pH, Salinity, Temperature $\left({ }^{\circ} \mathrm{C}\right)$ between Experimental (Es) and Control site (Cs) at $0.5 \mathrm{~m}$ depths for 12 months.

The higher growth rate in the $2^{\text {nd }}$ planting cycle, accompanied by a better quality of thalli as contrasted with other planting cycles can be attributed to lesser ice-ice disease, moderate to strong wind due to north-east monsoon (from January to March) enough to shake the cultivars to rid of fouling organisms, good water movement to facilitate nutrient uptake, and ideal salinity (at 34-35psu) and temperature (27 to $28^{\circ} \mathrm{C}$ ). In tropical waters like Indonesia, Eucheuma denticulatum grows well above a salinity of $30 \mathrm{psu}$ and a temperature range of 25 to $29{ }^{\circ} \mathrm{C} .{ }^{18}$ Other varieties of eucheumoids in the Philippines can grow better even at above $30{ }^{\circ} \mathrm{C} .{ }^{19} \mathrm{~A}$ decrease or increase in salinity and increase in temperature can cause stress to the seaweed that could bring to ice-ice disease. Conversely, E. denticulatum in the 2nd planting cycle for $15^{\text {th }}$ and $30^{\text {th }}$ day sampling substantially grew within the salinity of 34 to $35 \mathrm{psu}$ and temperature at 27 to $28^{\circ} \mathrm{C}$ and when there were less herbivorous fish in the culture area (personal observation).

Dissolved oxygen (DO) for 12 months from the experimental and control site went from 5.17 to 6.48 and 5.05 to $6.77 \mathrm{mg} / \mathrm{L}$, respectively. This oxygen level was within the normal range for coastal waters based on DENR DAO 2016-08 to be at least $5 \mathrm{mg} / \mathrm{L}$ and up, and it may be diverse at the bottom of the fish farm where oxygen levels could be comparatively low. Adequate DO is essential to fish farm operation. $^{21}$ The highest DO readings occurred in December 2018 with $6.48 \mathrm{mg} / \mathrm{L}$, while least readings were recorded in November 2018 with 5.17. If dissolved oxygen values were to be used as an indicator of flushing activity, its higher average value in the control site would show that this was the case as compared to the experimental site where its average value was low. This can also be seen in the average $\mathrm{pH}$ value over a 12-month period where the experimental site had lower average $\mathrm{pH}$ than the control site.

\section{Measurements of inorganic nutrients as primary indicator of water quality during the culture period}

Inorganic nutrients in the form of nitrate, ammonia, and phosphate showed little variations in average values between the experimental and control sites (Figure 6a and 6b).The fluctuations were observed on a monthly basis before and during IMTA implementation in both experimental and control sites. Phosphate had the highest concentration in August $2018(0.78 \mathrm{mg} / \mathrm{L})$, which was before the implementation of IMTA in the experimental site. It was then taken over by nitrate during IMTA implementation in March $(0.547 \mathrm{mg} / \mathrm{L})$ and April 2019 $(0.376 \mathrm{mg} / \mathrm{L})$ as the dominant nutrient with highest concentration in the experimental and control sites. The increase in nitrate from March and April 2019, matched the peak production periods of milkfish in both experimental and control cages entailing the increased amount of commercial feeds provided to the fish. Ammonia, which is among the waste products of the cultured aquatic animals, remained low before IMTA $(0.027 \mathrm{mg} / \mathrm{L}$ in August - November 2018). It rose up higher than phosphate during IMTA implementation $(0.058 \mathrm{mg} / \mathrm{L}$ from January to July 2019) in the experimental site, even when the inorganic extractive species (i.e. seaweeds) was deployed. Generally, $0.02 \mathrm{mg} / \mathrm{L}$ value of ammonia in water is harmless (PHILMINAQ, 2008). When all values for nutrients at $0.5 \mathrm{~m}$ were averaged over the 11-month study period, ammonia was also lower at near the surface in the experimental than in the control site. This was in contrast to nitrate and phosphate which were both higher in the experimental than in the control site. For comparison, the ammonia and phosphate concentrations decreased significantly in the experimental site $\left(\mathrm{F}_{\text {stat }}=\right.$ 0.596 and 5.576, respectively, $\mathrm{p}<0.05$ ) (see Table 3) during the deployment of $E$. denticulatum over a 6 month period.

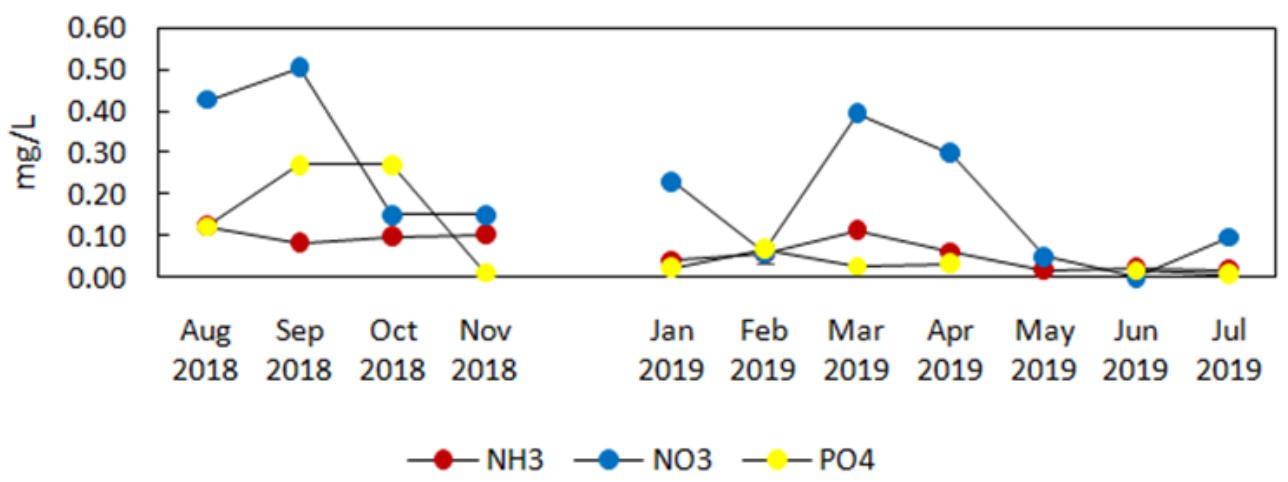

Figure 6a Monthly average nutrient concentration of experimental site (before and during placement of IMTA) for II months monitoring (depth, $0.5 \mathrm{~m}$ ). 


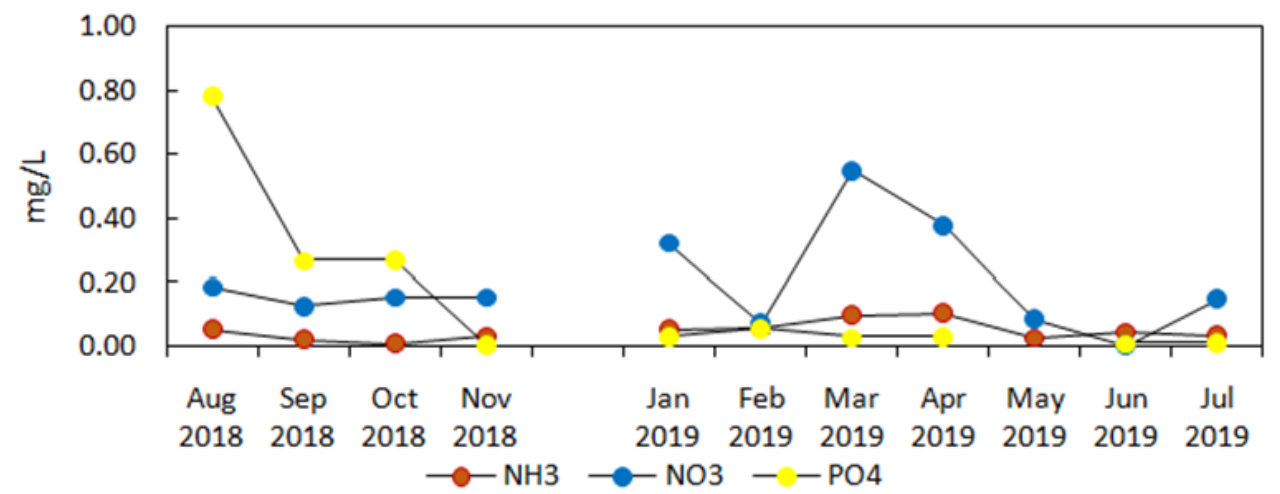

Figure 6b Monthly average nutrient concentration in the control site during II months monitoring (depth, $0.5 \mathrm{~m})$.

Table 3 Comparison of seawater nutrients (replicated) from study site and control site for 6 months in $0.5 \mathrm{~m}$ depth

\begin{tabular}{|c|c|c|c|c|}
\hline Treatment & & $\mathrm{NH}_{3}(\mathrm{mg} / \mathrm{L})$ & $\mathrm{NO}_{3}(\mathrm{mg} / \mathrm{L})$ & $\mathrm{PO}_{4}(\mathrm{mg} / \mathrm{L})$ \\
\hline \multirow{6}{*}{ Experimental } & Mos & 11 & 11 & $10 *$ \\
\hline & Average & 0.047 & 0.226 & 0.149 \\
\hline & Min & 0.006 & 0.003 & 0.005 \\
\hline & Max & 0.104 & 0.847 & 0.780 \\
\hline & Variance & 0.001 & 0.054 & 0.060 \\
\hline & SE & 0.009 & 0.070 & 0.077 \\
\hline \multirow{9}{*}{ Control } & Mos & II & II & $10 *$ \\
\hline & Average & 0.068 & 0.215 & 0.085 \\
\hline & Min & 0.018 & 0.001 & 0.008 \\
\hline & Max & 0.124 & 0.504 & 0.271 \\
\hline & Variance & 0.002 & 0.029 & 0.011 \\
\hline & SE & 0.012 & 0.051 & 0.033 \\
\hline & $d f$ & 10 & 10 & 9 \\
\hline & $F$ value & 0.596 & 1.883 & 5.576 \\
\hline & F critical & 0.336 & 2.978 & 3.179 \\
\hline
\end{tabular}

* no phosphate was conducted during May 2019

The study sites can be contrasted more in terms of their hydrodynamics which could explain the difference in their water quality in terms of nutrients. For instance, the INCA circular fish cages (as control site) being positioned in a deeper portion (about $35 \mathrm{~m}$ deep), has a more dynamic water exchange and efficient flushing capacity for wastes coming from the fed fish, resulting to the lower concentration for nitrate and phosphate $(0.215$ and $0.085 \mathrm{mg} / \mathrm{L}$, respectively), near the surface. In contrast, the experimental site, which was set in relatively shallow depths of only 13 to $15 \mathrm{~m}$ during low tide had relatively high average concentrations of nitrate and phosphate $(0.226$ and $0.149 \mathrm{mg} / \mathrm{L}$, respectively) over the same 11 -month study period (Table 3). Ammonia appeared to be unreduced by water circulation in the control site (with conc. of $0.068 \mathrm{mg} / \mathrm{L}$ ). An F comparison test between the two sites showed a significant difference between sites for ammonia and phosphate but not in nitrate concentrations. Hung et al., ${ }^{22}$ conducting a study on the biogeochemical responses on the removal of mariculture structures in a eutrophied lagoon in Taiwan, explained that the additional inputs of nutrients into the lagoon could be coming from external sources aside from the mariculture structures (i.e. discharges from land-based wastes) which are being carried by the river into the sea. This situation is possibly the case also in Carcar Bay, where the fish farm is located close to a river from which additional concentration of nutrients could have come from. The river is $575 \mathrm{~m}$ apart from experimental cages, and after rainy days (during selected dates of the months, from January to June 2019), land-based waste such as diapers, fecal wastes, plastics with organic items, and other sanitary products from residential areas near the river has been presumed to have an impact on the growth of the IMTA species.

Higher tendencies of phosphate and ammonia in the water could be identified together with the expansion in water temperature during summer period and pervasiveness of anoxic conditions in profound waters which would offer ascent to organic deterioration - delivering ammonia and phosphate ions. ${ }^{23,24}$ Although the fish biomass (in INCA cages) in the control site would be 3 to 4 times higher in stocking densities (based on company information), requiring more feeds than those in the experimental site and where the released wastes coming 
from the cages expected to be enormous, the average concentrations of these nutrients were, however, relatively low (Table 3). It would appear from this study that the integration of $E$. denticulatum is working as a biofilter of these nutrients especially if concentrations between the experimental and control sites were compared. E. denticulatum and several other macroalgae (i.e. Gracilaria spp., Kappaphycus spp. Sargassum spp.) integrated into fish culture have been found in other studies $^{16,25,26}$ to be a good extractive species for nitrogenous wastes. Up to what extent the continuous feeding of the cultured fish will lead to a negative impact on the surrounding waters requires a long-term water quality assessment. Continuous water quality monitoring is, therefore, necessary to determine the environmental sustainability of the fish farming activities in Carcar Bay.

E. denticulatum and other seaweed species cultivated with fed species (as described in this study) in an IMTA set up, can be crucial to the sustainability of aquaculture farms. Depending on species, they can be primarily influenced by water temperature, salinity, $\mathrm{pH}$, and nutrients (ammonia, nitrate, and phosphate), depending not only on the extent of water movement, ${ }^{27}$ but also by the methods in which they are farmed vis-à-vis the main cultured species. For instance, seaweed culture can only be effective as an extractive component of IMTA if they are planted in very close proximity to the fish cages. ${ }^{28}$ In turn, these nutrients in the form of phosphate and nitrate were among the nutrients found to improve the growth rate of Eucheuma spp. ${ }^{12}$ and other macroalgae, ${ }^{18,29}$ although phosphates in higher concentration can also be toxic to macroalgae. However, ammonia, released as a waste product from fed species such as fin fishes, can have the potential to reduce $\mathrm{pH}$ levels in seawater on a short-term basis, which is detrimental to the health of marine organisms especially to those with skeletal elements made of calcium carbonate. Considering the excessive introduction of carbon dioxide into the oceans, the $\mathrm{pH}$ of seawater is expected to shift towards the acidic side although current model calculated $\mathrm{pH}$ show values to still hover around 8.2 with variation between 8.08 and $8.33 .{ }^{31}$ DENR Administrative Order (DAO) 2016-08-WQG under the classification of the marine waters in the Philippines for its commercial use placed water quality standard to have a pH range of 6.5-8.5 and a dissolved oxygen of $5.0 \mathrm{mg} / \mathrm{L} .^{32-37}$

\section{Conclusions}

The combined culture of Eucheuma denticulatum with an existing commercial cage-culture of milkfish/pompano in Carcar Bay, southern Cebu Province, forming an integrated multi-trophic aquaculture (IMTA) system, proved to be highly feasible. This seaweed has adopted well in the system growing at a specific rate of $1.85 \pm 0.54 \%$ day $^{-1}$ over 6 months in culture. Whereas, the growth rate in in the $1^{\text {st }}$ planting cycle (November-December 2018) with 1.22 $\pm 0.73 \%$ day $^{-1}$ wasthe lowest among the 4 planting cycles. The lower than normal growth rate can also be encountered in most seaweed farms here in the Philippines due to the effects of epiphytism, iceice disease, and grazing, and was still considered an acceptable rate. Heavy rains and strong winds especially during the occurrence of typhoons in both experimental and control sites caused minimal growth of E. denticulatum from the planting site. The presence of herbivores, the suspended solids coming from the river other than feeds, and successive occurrence of warmer days, can be the reasons for the decrease in biomass of $E$. denticulatum per planting cycle.

For the entire 12 month monitoring of the physico-chemical parameters, the water temperature has an average range of $29.27 \pm 0.14^{\circ} \mathrm{C}, 34.72 \pm 0.12 \mathrm{psu}$ for salinity, $5.67 \pm 0.27 \mathrm{mg} / \mathrm{L}$ for $\mathrm{DO}$, and $7.91 \pm 0.15$ for $\mathrm{pH}$. These were found to be within the optimal range that are favorable for the open sea culture of fed fin fishes and for Eucheuma denticulatum. The F (two-tailed) comparison of the two sites shows that ammonia and phosphate $\mathrm{F}_{\text {stat }}$ value are higher than its $\mathrm{F}_{\text {critica }} 1$ value. Ammonia and phosphate were utilized efficiently as a reason of the decreased over the full 6 months of monitoring during the placement of Eucheuma denticulatum at the experimental site.The average monthly ammonia level at the experimental site is $0.047 \mathrm{mg} / \mathrm{L}$ and $0.149 \mathrm{mg} / \mathrm{L}$ for phosphate. Based on these results, it is therefore advisable to use efficient natural biofilter such as Eucheuma denticulatum as co-cultured species in the commercial fish cage farming of milkfish/pompano to absorb excess nutrients.

\section{Recommendations}

a. Corollary to this research, population structure of the selected macro-algae must be conducted to assess their potential genetic consequences of interbreeding between farmed and wild stocks.

b. Aquaculture infrastructure are being improved in many places in South East Asian regions, like in the Philippines. However, this have caused consequent changes in water circulation and water quality deterioration of the aquaculture sites, often resulting to reduced oxygen levels, flow rates and accumulations of particulate organic matter and dissolved inorganic nutrients. The incorporation of modern technologies (e.g. wireless sensors) for real-time water quality monitoring in the aquaculture system is becoming a necessity and is highly recommended.

\section{Conflicts of interest}

The author declares that there are no conflicts of interest.

\section{Funding}

None.

\section{Acknowledgments}

Special thanks are due to Carcar Cebu Prawn Farm Research Laboratory and its technical personnel, Fish Farm Manager - Peter Villamor and Supervisors - Eric Pulvera and Leonides T. Candado, for providing the necessary secondary data, accommodation, use of facilities and technical assistance for the accomplishment of the cultures. I also thanked my Doctorate Adviser, Dr. Danilo B. Largo for sharing me his expert ideas and for the improvement of this article.

\section{References}

1. Holdt S, M Edwards. Cost-effective IMTA: a comparison of the production efficiencies of mussels and macroalgae. $J$ App Phycol. 2014;26(2):933-945.

2. Irisarri J, Cubillo AM, Fernandez-Reiriz MJ, et al. Growth variations within a farm of mussel (Mytilus galloprovincialis) held near fish cages: importance for the implementation of integrated aquaculture. Aqua Res. 2014;1-15.

3. Reid GK, Lefebvre S, Filgueira R, et al. Reviews in Aquaculture. Wiley Pub. Asia Pty. Ltd. 2018;1-29.

4. Schneider O, Sereti V, Eding EH, et al. Analysis of nutrient flows in integrated intensive aquaculture systems. Aqua Eng. 2005; 32(3-4):379401.

5. Costa-Pierce BA. Ecological aquaculture: The evolution of the blue revolution. Blackwell Science, Oxford, UK. 2002.

6. Troell M, Halling, C, Neori A, et al. Integrated mariculture: asking the right questions. Aquaculture. 2003;226:69-90. 
7. Kasim M, Mustafa A, Munier T, et al. The growth rate of seaweed (Eucheuma denticulatum) cultivated in longline and floating cage. AACL Bioflux. 2016;9(2)

8. Abreu MH, Valera D, Henríquez-Antipa L, et al. Traditional vs. integrated aquaculture of Gracilaria chilensis C.J. Bird, Mclachlan et E.C. Oliveira: Productivity and physiological performance. Aquaculture. 2009;293(3): 211-220

9. Neori A, Chopin T, Troell $\mathrm{M}$, et al. Integrated aquaculture: rationale, evolution and state of the art emphasizing seaweed biofiltration in modern mariculture. Aquaculture. 2004;231(1-4):361-391.

10. Food \& Agriculture Organization (FAO). Fisheries and aquaculture statistics. 2017.

11. Kambey CSB, Sondak CFA, Chung, I. Potential growth and nutrient removal Of Kappaphycus alvarezii in a fish floating-net cagesystem in Sekotong Bay, Lombok, Indonesia. J World Aqua. Soc. 2020;51: 944-959.

12. Sahoo D, Ohno M, Hiraoka M. Laboratory, field and deep seawater culture of Eucheumaserra - a high lectin yielding red alga. Algae. 2002;17(2):127-133.

13. Vairappan CS. Seasonal Occurrences of Epiphytic Algae on the Commercially Cultivated Red Alga Kappaphycus Alvarezii (Solieriaceae, Gigartinales, Rhodophyta). J App Phyco. 2006;18(3):611-617.

14. Titlyanov EA, TV Titlyanova. Seaweed cultivation: Methods and problems. Russian J Mar Biol. 2010;36(4):227-242.

15. Kasim M, Mustafa A, Male I, et al. New methods on cultivation of Eucheuma denticulatum and Kappahycus alvarezii in Indonesia. J Fish Aqua Sci. 2017;12: 207-217.

16. Kim JK, Pereira P, Yarish C. Tolerances to hypo-osmotic and temperature stresses in native and invasive Gracilaria species. Phycologia. 2016;55(3):257-264

17. Lideman L, Nishihara G, Noro T. Effect of temperature and light on the photosynthesis as measured by chlorophyll fluorescence of cultured Eucheuma denticulatum and Kappaphycus sp. (Sumba strain) from Indonesia. J Appl Phycol. 2013;25(2):399-406.

18. Kasim M, Mustafa A, Ishak E, Ibrahim MN, et al. Environmental status of Kappaphycus alvarezii cultivation area following temporary eutrophication. AACL Bioflux. 2019;12(4):1102-1113.

19. Villanueva R, Romero JB, Montaño MNE, et al. Harvest optimization of four Kappaphycus species from the Philippines. Biomass and Bioenergy. 2011;35(3):1311-1316.

20. Price C, Black KD, Hargrave BT, et al.. Marine cage culture and the environment: effects on water quality and primary production. Aqua Environ Interact. 2015;6(2):151-174.

21. Hung JJ, Hung CS, Su HM. Biogeochemical responses to the removal of maricultural structures from an eutrophic lagoon (Tapong Bay) in Taiwan. Mar Environ Res. 2008;65(1):1-17.

22. Markoua, D.A. et al., 2007. Water quality of Vistonis Lagoon, Northern Greece: seasonal variation and impact of bottom sediments. Desalination 210: 83-97.
23. Spears BM, Carvalho L, Perkins R, et al. Effects of light on sediment nutrient flux and water column nutrient stoichiometry in a shallow lake. Water Res. 2008;42 (4-5):977-986.

24. Abreu MH, Pereira R, Yarish C, et al. IMTA with Gracilaria vermiculophylla: Productivity and nutrient removal performance of the seaweed in a land-based pilot scale system. Aquaculture. 2011;312(14):77-87.

25. Zheng $\mathrm{Y}$, Jin $\mathrm{R}$, Zhang $\mathrm{X}$, et al. The considerable environmental benefits of seaweed aquaculture in China. Stochastic Environmental Research and Risk Assessment. 2019.

26. Neish IC. The ABC of Eucheuma sea plant production: Agronomy, biology and crop-handling of Betaphycus, Eucheuma and Kappaphycus the gelatinae, spinosum and cottonii of commerce. 2003.

27. Largo DB, Diola AG, Marababol MS. Development of an integrated multi-trophic aquaculture (IMTA) system for tropical marine species in Southern Cebu, Central Philippines. Aqua Rep. 2016;3:67-76.

28. Teichberg M, Fox SE, Olsen YS. Eutrophication and macroalgal blooms in temperate and tropical coastal waters: nutrient enrichment experiments with Ulva spp. Global Change Biology. 2010;16(9):2624-2637.

29. Moheimani NR, Nwoba EG, Owen BM, et al.. Bio-prospecting and growth of macroalgae on anaerobic digestion piggery effluent (ADPE). Cooperatives Research Center (CRC) Programme. 2016; 66 p.

30. Marion GM, FJ Millero MF, Camoes P, et al. pH of seawater. Mar Chem 2011;126:89-96.

31. Chopin T, S Robinson. Defining the appropriate regulatory and policy framework for the development of integrated multi-trophic aquaculture practices: introduction to the workshop and positioning of the issues. Bull Aqua Assoc Can. 2004;104(3):4-10

32. Department of Environment and Natural Resources (DENR), Philippines, Administrative Order No. 08. Series of 2016. Updates on Water Usage and Classification/ Water Quality Criteria.

33. http://www.fao.org/fishery/ensearched on 8 Jan. 2018.

34. Food \& Agriculture Organization (FAO). The state of world fisheries and aquaculture 2010. Food and Agriculture Organization of The United Nations, Rome. 2010

35. Pereira R, C Yarish. Mass production of marine macroalgae. In book: Encyclopedia of Ecology. Vol. 3. Ecol. Eng. Elsevier, Oxford. 2008. p. 2236-2247.

36. PHILMINAQ. Water quality criteria and standards for freshwater and marine aquaculture (Annex 2). Mitigating Impact of Aquaculture in the Philippines. Diliman, Quezon City. 2008; 97 p.

37. Yong WTL, Ting SH, Chin WL, et al. In vitro micropropagation of Eucheuma seaweeds. $2^{\text {nd }}$ Int'l. Conf. on Biotech. and Food Sci. In: IPCBEE. 2011;7. p. 58-60. 